\title{
PERFORMANCE ANALYSIS OF REITS: COMPARISON BETWEEN M-REITS AND UK-REITS
}

\author{
Anuar Alias ${ }^{1} \&$ Soi Tho C.Y. \\ Centre for Building, Construction and Urban Studies (CeBUS) \\ Faculty of Built Environment \\ University of Malaya ${ }^{1}$ \\ Email: anuar_a@um.edu.my ${ }^{1}$
}

\begin{abstract}
Real Estate Investment Trusts or more commonly known as REITs is one of the investment tools that is renowned for the nature of low risk, low volatility, moderate returns, and high liquidity for investors. REITS invest primarily in real properties and tend to receive regular rental incomes from real properties owned and managed by the Trust. In most situations, it may be deemed as a stock by investors. However, the risk borne is lower and has less fluctuations in terms of market price of the stock. Moderate risk takers should consider REITS as one of the investments in their portfolio. REITS started emerging in many countries only recently. Since the successful of the performance of REITs in the United States, numerous countries started planning to enter the REITs regime. The United Kingdom was one of the recent countries to enter into the tax efficient REITs regime. This took place early in the year 2007. At the moment, it ranks fourth in terms of market capitalization based on the Global REITs report 2008. Malaysia, with a long history of Unit Trust Funds with some recently converting to REIT, has yet to achieve the size of UK-REITs. This research is to analyse the performance of six (6) selected REITs in both countries. Nevertheless, prior to the performance analysis, the mechanism as well as the legislation adopted in regulating the respective REITs regime is discussed. In addition, factors which contributed to the variance of performance of REITs are presented and further discussions are made based on the performance analysis done. The findings and analysis showed that the total revenue was the main factor affecting the performance for both the largest M-REITs and UK-REITs. Furthermore, has also demonstrated that for every billion increase in market capitalisation, the profit margins generated by the REITs will raise by approximately $9 \%$.
\end{abstract}

Keywords: REITs, Performance analysis, M-REITs, UK-REITs

\section{Background}

The Securities Commission of Malaysia defines REITs as "an investment vehicle that proposes to invest at least $50 \%$ of its total assets in real estate, whether through direct ownership or through a single purpose company whose principal asset comprises of real estate". Shares of REITs companies are publicly traded in the major stock exchange and it is viewed as a good way for investors to own a property indirectly by owning the shares of the property. It would also be the only way for ordinary investors to have the opportunity to invest in large scale commercial properties. REITs usually generate income by owning and operating income producing real property such as offices, shopping centres and service apartments. Meanwhile it may invest in real estaterelated securities, cash or fixed deposit and whole loans. However, most of the earning of a REIT company is produced from the recurrent rental incomes of the real properties owned. The unit-holders of REITs will receive return in the form of dividends from the net income of the REITs generated. Due to the stable flow of incomes, it is considered as a lower risk investment tool to the investors.

REITs are considered to be under the category of unit trust funds which are being professionally managed. The organisation structure is alike for both REITs and unit trust funds. In the case of Malaysia, experienced real estate professionals would be appointed as the management team of REITs which must be headed by a registered valuer to manage the investment and operations of REITs. It would be the same for trust funds where other than the management company, a professional fund manager will select and manage the 
investment. The management team of REITs are accountable both to their board of directors as well as the shareholders of the REITs. However there are REITs which are internally managed by the company whereby the management fees could be saved.

REITs are viewed as the best combination of investment in real property and stocks. Investment in REITs by buying the shares of REITs would provide the investors a way to reduce loan and interest paid to own a property as investment. The return is indeed lower then stocks but would be more stable as it generates stable incomes to REITs. This is the uniqueness of investing in REITs and the awareness of this profit-driven investment tool has been raised recently.

This investment tool has a long history in the United States and Australia which had been achieving stable markets and growth over the past ten years. REITs had started becoming popular and achieving growth in many of the South East Asia countries in recent years, for instance, Singapore and Japan. REITs are considered as a new concept in Malaysia (since 2005) which is the transformation to property trust funds. The Securities Commission is the core regulator of all the unit trust funds and REITs are responsible in monitoring development of the industry. This statutory body had issue new guidelines for REITs on the 3rd January 2005 to replace the old rule for Property Trust Funds. The issuance of the new guideline has indeed been promoting the REITs due to the one level of taxation.

The REITs market is different from country to country, as well as for the determinant factors of the performance of REITs in the specific market. Regulation is believed to be the main dissimilarity among the REITs of different countries. Besides that, several factors for instance, property market climate of the country may in fact influence the performance of the REITs for the country directly as well. The REITs market is successful in many countries, especially The United States which had matured in the REITs market. Many countries started introducing the REIT regime and are making efforts to develop this industry as it is one of the most valuable investment that can contribute to the growth of the economy of the country. The United Kingdom was one of the countries which has newly entered into the REIT regime. The REIT legislation was introduced by the United Kingdom government on the 1st of January, 2007 and this had attracted ten property companies to be converted into the REITs status on the first date of the REITs introduction.

Interestingly, within about three years of the introduction to the market, it had achieved the ranking of fourth in terms of the total market capitalisation, which was about US\$ 41 million (Global REITs Report 2008, Earnst \& Young). It is believed that there may be several underlying factors which contributed to the escalated growth of UK-REITs to become impressive in the global REITs market. For instance, the differences in terms of management and the regulations of the REITs industry would probably the causes. The performance analysis of this newly introduced REITs market would no doubt interesting since it is new market to the global REITs industry, not much research had been done by the researchers. Furthermore, the impressive market capitalization does not means that the return of investment to the investors is high compared to other investment options. MREITs with a lower total market capitalization are proved to be performing well and the return to the investors is guaranteed. Therefore, a study on REITs of the two countries in fact would reflect the extent of successfulness of the REITs market of respective countries. 


\section{2. $\quad$ Research Objectives}

This study attempts to achieve the following objectives:

- $\quad$ To study the concept, mechanism and regulation of REITS in Malaysia and the United Kingdom

- To analyze the performance of the selected REITS of Malaysia and the United Kingdom

- To identify the factors which contribute to the variability of performances for M-REITS and UKREITS

\section{Scope of Research}

This study focuses on the performance of M-REITS and UK-REITS. The three (3) largest REITS in terms of market capitalisation of both countries was chosen for the performance analysis. The market capitalisation is determined as at $31^{\text {st }}$ December 2009. A list of REITs in Malaysia and UK is attached in the Appendix I and II. The REITS' companies chosen must be listed in their respective stock market, i.e. be listed in Bursa Malaysia for M-REITS and London Stock Exchange for UK-REITS. The analysis could only be done for a limited number of REITS due to time constraint. Complexities and diversities could be reduced significantly while limited to few numbers of REITs.

The collection of data for this study lies between the timeframe of 2007 to 2009. This is due to the reason that REITs of United Kingdom was introduced on the 1st of January 2007. The financial data for the purpose of performance analysis of each REIT will be limited until year 2008 with some exceptions for REITs company that have their financial year ending at March 2009.

\section{Research Methodology}

Qualitative methods by way of observation and case study will be adopted as the research methodology. Relevant financial data in different forms such as statistics, graphs, charts obtained will be analyzed in order to compare the variability of performance of the selected REITs in UK and in Malaysia. The data is extracted from the annual report of the REITs companies, Bursa Malaysia, London Stock Exchange and on the online database, namely Thomson One Banker. Secondary sources will be considered as well, for instance, articles, journals, research papers, reference books and the guidelines for REITs published by the Securities Commission in the Malaysia context and the guidelines and regulations in the United Kingdom context.

\section{Brief Literature Review}

In this section, an overview of REITs will be explained in the context of Malaysia and UK. Focus will be given to the aspects of the general mechanism, establishment of REITs market and legal issues relating to each respective country. Besides that, factors contributing to the difference of performance of a REIT will be discussed in the last section. Lastly, all related facts and arguments of REITs based on previous studies done will be discussed and clarified further. 


\subsection{Fundamental of REITs}

Real Estate Investment Trusts (REITs) is one of the investment tools for investors in generating attractive returns other than investing in bonds, unit trust, shares and direct ownership of real property. In fact, investors who buy the units of REITs is indirectly an owner of a vast real estate portfolio.

REITs company as a real estate company invest primarily in income producing real estate and must own at least RM 100 million in real estate (in the context of Malaysia) offer the opportunity for small investors to participate in a broad range of real estate. This unique feature does not happen for investment in direct ownership of real property due to un-affordability of investors. The management of REITs will invest and manage their properties in such a way that steady income could generate. Simultaneously, they will have an eye to the future and are expected to see to the growth of the property portfolio and its cash flows, and to take advantage of new opportunities (Block, 2006).

The REITs concept is applied mostly in the same way in several countries in the world and they share a common feature such that they are responsible to distribute most of their income to unit-holders in the form of dividends. The company will not be charged for taxation at the corporate level, if this aspect is fulfilled by the company. This is regarded as the biggest advantage to the company. The only difference is at the REITs structure adopted for different countries with their predetermined legislation before establishment of REITs in monitoring the REITs sector. In addition, as far as Malaysia is concerned, REITs companies are professionally managed by a group of people lead by a manager who must be a registered valuer in making all the decisions for all the investments. Thus, investors may rely upon this group of professionals in managing the REITs.

\subsection{Characteristics of REITs}

As compared with other investment tools such as stocks, REITs enjoys the unique characteristics which are usually not enjoyed by the others, namely low correlation with other asset classes, low market-price volatility, limited investment risk and high current yield (Block, 2006). These uniqueness of REITs will also impact on the total portfolio performance. Correlations determine how much predictive power the price behaviour of one asset class has on another to which it's compared (Block, 2006). In the investment world, correlations play a vital role owing to the reason that it enables investment consultants, financial planners and investors to structure broadly diversified investment portfolios with the purpose of having the ups and downs of each asset class. Previous studies done by Ibbotson Association completed in 2001 and updated in 2003 found that the correlation of REITs returns with other investments had drop significantly when measured over various time periods from 1967. The nature of highly non-correlated REITs offers the means for additional portfolio diversification (Brinson, 1986). Volatility, according to The Free Dictionary (financial), is the measure of a security's stability by adopting the standard deviation from a certain continuously compounded return over a given period of time in order to quantify the risk.

A lower volatility means that a security's value does not fluctuate dramatically but changes in value at a steady pace over a period of time. REITs tends have low volatility than other equities from the observations of the REITs market over the last thirty years on a daily basis (Imperiale, 2006). Risk exists for any type of investments and there is no way to avoid risk completely in any period of time, including the investment in REITs. Commonly, the higher the volatility, the riskier is the security, however it tends to provide higher returns. In other words, these three factors are inter-related. Imperiale (2006) also stated that with a risk profile slightly higher than of bonds and a return profile slightly lower than that of stocks, REITs give competitive returns to investors for the risk assumed. In addition, REITs act as a liquid asset in the share market. Liquidity indicates how easily an asset is bought and sold in the market or converted into cash. REITs possess the feature of high liquidity as enjoyed by most publicly traded stock. 


\subsection{Malaysia REITs}

\subsubsection{Development of REITs in Malaysia}

Real Estate Investment Trusts (REITs) in the United States and Listed Property Trusts (LPTs) in Australia have a long and successful history as an effective real estate investment vehicle (Joseph et al, 2006). Listed Property Trusts was first introduced in Asia by Malaysia in 1989. The first trust listed on the Kuala Lumpur Stock Exchange (KLSE) was Arab Malaysia First Property Trust in August of 1989. Despite Malaysia, being the first Asian country to develop Listed Property Trusts, the industry has had a slow movement according to Newell, et al (2002). It is further pointed out by Newell et al. (2002) that local structural and regulatory factors are the underlying reasons for the slow and poor performance of listed property trusts in Malaysia. After the year 2005, Listed Property Trusts in Malaysia had transformed into or renamed to a more globally adopted term, known as Real Estate Investment Trusts (REITs). New guidelines had been issued by the Securities Commission to provide a legal framework for better monitoring of the newly introduced REITs. Table 1 shows the major policy changes of the REITs regime from the earlier form of property trust fund in Malaysia.

Table 1: Major policy changes of REITs regime in Malaysia

\begin{tabular}{|c|c|}
\hline Date & Descriptions of Policy \\
\hline 1986 & $\begin{array}{l}\text { Approval of the establishment of regulatory framework of listed property trusts } \\
\text { by the Central Bank of Malaysia. The principal regulation was the Companies Act } \\
1965 \text { and Securities Industry Act } 1983 \text {. }\end{array}$ \\
\hline 1989 & $\begin{array}{l}\text { In order to provide a framework for the establishment of property trust fund in } \\
\text { Malaysia, Property Trust Guideline (PTG) was issued. }\end{array}$ \\
\hline October 1991 & Specific Securities Commission guidelines for property trust fund was developed. \\
\hline $16^{\text {th }}$ June 1995 & The first edition of Guidelines on Property Trust Funds was issued by SC. \\
\hline $13^{\text {th }}$ November 2001 & SC revised the Guidelines on Property Trust Funds ( $2^{\text {nd }}$ Edition $)$. \\
\hline 2004 & $\begin{array}{l}\text { Announcement by the government that RPGT and stamp duty are exempted for } \\
\text { sale of property to REITs. }\end{array}$ \\
\hline $3^{\text {rd }}$ January 2005 & $\begin{array}{l}\text { Guidelines on Real Property Investment Trusts (REITs) were issued (3rd } \\
\text { Edition).Tax transparency for REITs was announced by government. }\end{array}$ \\
\hline $30^{\text {th }}$ September 2005 & $\begin{array}{l}\text { In order to reduce the cost of establishment of REIT, government announced to } \\
\text { allow tax deductions on legal, valuation and consultancy expenses incurred in the } \\
\text { establishment of REITs. }\end{array}$ \\
\hline $21^{\text {st }}$ November 2005 & The issuance of Guidelines on Islamic Real Estate Investment Trusts. \\
\hline
\end{tabular}

Source: Chin \& Rubi Ahmad, 2006 


\subsubsection{Structure of M-REITs}

Figure 1 shows the structure of Malaysian REITs as demonstrated by Phuah (2005).

Figure 1: Structure of Malaysian REITs

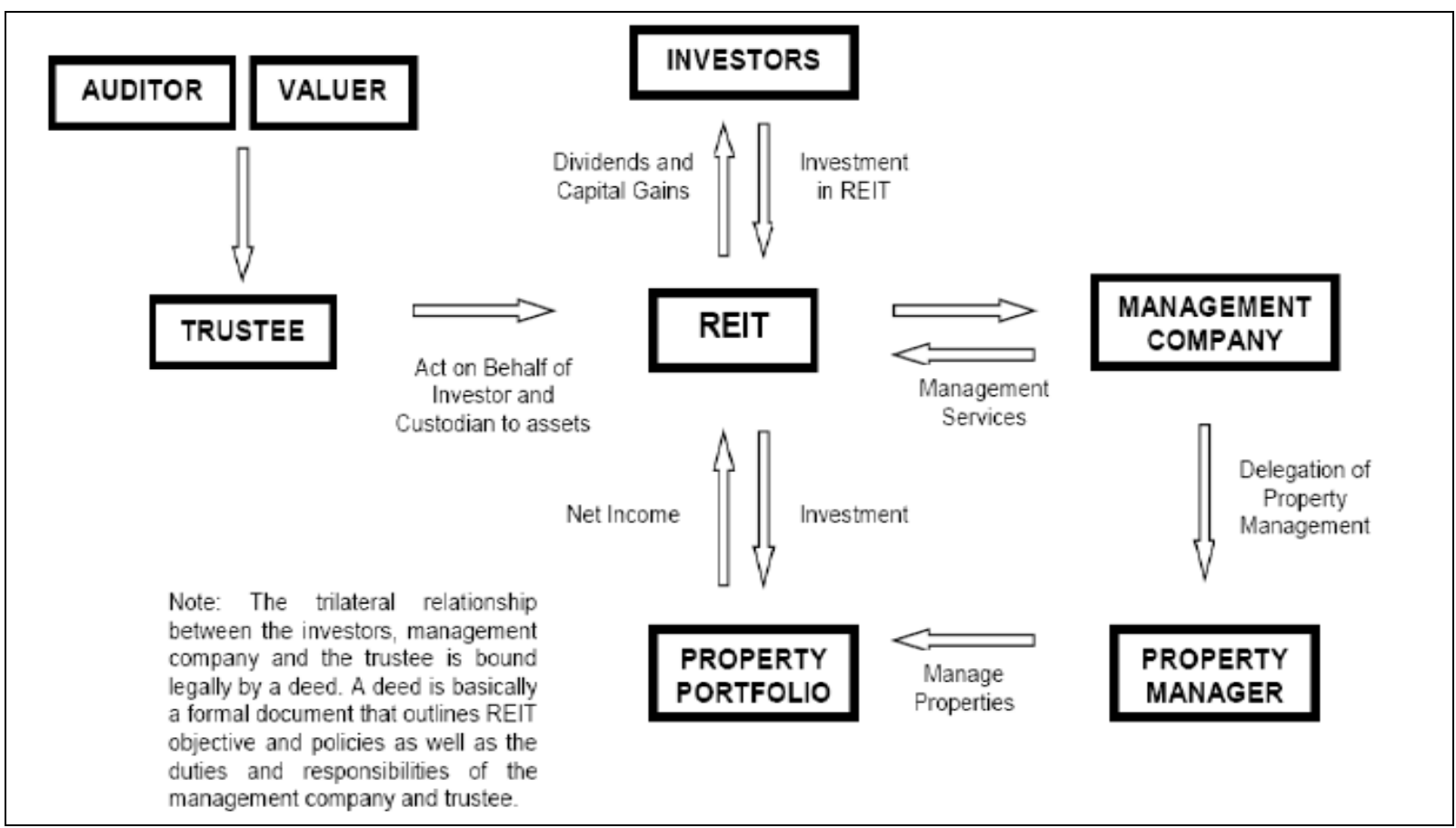

Source: Phuah (2005)

\subsubsection{The Governance of M-REITs}

In Malaysia, REITs are governed by a statutory body known as Securities Commission (SC) with investigative and enforcement powers granted under the Securities Commission Act 1993. REITs are generally regulated by the SC through the following guidelines and legislations (Shahrin Shaikh Mohd, 2006):-

Securities Commission Act 1993

Guidelines on Real Estate Investment Trusts 2008

$\checkmark$ Guidelines on Islamic REIT

Guidelines on Asset Valuation

All the guidelines were issued by the SC as pursuant to Section 158 of the Securities Commission Act. Any breaches or non-compliance of any of the requirements may cause administrative sanction under the guidelines or securities laws. Other laws and guidelines which also contributed in regulatory function of REITs are as follows:-

Securities Industry Act 1993

$\square$ Guidelines on Unit Trust Funds

$\square$ The Listing Rules of Bursa Malaysia

Capital Markets and Services Act, 2007 (CMSA)

$\checkmark$ Malaysia Income Tax Act, 1967 (MITA) 
$\square$ Valuers, Appraisers and Estate Agents Act 1981

$\square$ Foreign Investment Commission (FIC) Guidelines

Under the Securities Act 1993, several matters are required for approval. For instance:-

$\square$ For the offering and issuance of REIT units or the establishment of a REIT

$\checkmark$ For a company to act as a REIT manager

$\square$ For a trust company to act as trustee

$\neg$ For the listing of a REIT on Bursa Securities

Whereas under the Guidelines, the matters need approval are:-

$\square$ Approval on valuation of real estates for certain types of acquisition and revaluation of real estates

Approval for the appointment of the Board members, Investment Committee members and CEO of a REIT Manager

Approval for any exemptions or waivers that may be required

Approval for delegation of any function to a delegate

\subsubsection{Future of M-REITs}

The development of M-REITs is expected to have more improvements in the future hoping for more REITs to be listed on the Bursa Malaysia. Currently the total market capitalisation of M-REITs is about US\$ 1.43 billion according to the latest Asian Public Real Estate Association Weekly REIT report. In terms of the total market capitalisation, Malaysia is still behind as compared to other Asian countries, namely, Singapore (US\$ 15.1 billion), Hong Kong (US\$ 8.3 billion), Taiwan (US\$ 1.53 billion) and Thailand (US\$ 1.52 billion)(extracted from The Star news on 17 August 2009). However, two important announcements by the Government recently, which are the liberalisation of Foreign Investment Committee (FIC) Guidelines regarding the purchased of properties by foreigners and the removal of $30 \%$ bumiputera condition in listed companies, would attract more REITs going into the market. More foreign investors are expected to be coming into the market, thus stimulating the existing market.

According to the Axis REIT Managers Bhd chief executive officer-cum-executive director Stewart LaBrooy, they will be two new REITs for listing on Bursa Malaysia in the next few quarters. The two REITs are the Sunway City Bhd's (SunCity) REIT and CapitaLand Ltd of Singapore's REIT. He further pointed out that it would be possible that the listing of SunCity REIT in the coming year will replace Starhill REIT as the largest REIT in the country as it is backed by RM 3.7 billion worth of assets. "CapitaLand's REIT, with an initial asset size of RM2bil, was targeted to be the country's first foreign-sponsored REIT on the Bursa. The company had intended to inject its three shopping malls in Malaysia - Gurney Plaza in Penang, the Mines Shopping Fair in Seri Kembangan, Selangor, and Sungei Wang Plaza in Kuala Lumpur - into the REIT. The proposed listing of the two REITs was initially planned for this year but had to be deferred due to the weak stock market conditions following the global financial crisis. It is understood from management that the timing for its proposed listings would be subject to market conditions going forward" (extracted from The Star news 6th July 2009). "With 11 listed REITs and two property trusts in the country now, there is room for more of these trust funds," said 
Stewart LaBrooy. Nonetheless, some REITs are planning to expand their property portfolios and upgrading their existing portfolios. For instance, Axis REITs had implemented asset enhancement strategy by upgrading their assets regularly for the increased value of those assets. The recent upgrading of Axis property was done which is the Wisma Kemajuan in Petaling which brought in asset value appreciation. There is also a need for a higher retail investor participation in the REIT market as currently the market liquidity is still low. This can be addressed by expanding portfolios and market capitalisation of each of the listed funds.

\subsection{UK REITs}

\subsubsection{The Introduction of UK-REITs at 1st January 2007}

UK-REITs is considered new to the global REITs market where it only came into force on 1st January 2007 with the Finance Act of 2006 of July 19 (Table 2). Yet, according to REITA (2009), the intention of the UK government to launch REITs was first announced back in 1997 with the aim to increase the competitiveness of the UK property market with other global economies. Another reason for the introduction of REITs is the government desire to stem the flow of capital into offshore property funds which are exempted from income tax, such as Jersey property trust funds. A long period had been taken by the government for consultation for the launch of UK-REITs. Major issues that were needed to be resolved are the tax and regulatory issues. Undoubtedly, in order for the successful development of UK-REITs in the market, these two issues are vital as they play the role of regulatory framework of the development of REITs.

Consequently, according to REITA (2009.), the parties involved in direct consultation with the UK Government are inclusive of many members of The REITs and Quoted Property Groups as well as the British Property Federation (BPF), the Investment Property Forum (IPF) and the Royal Institution of Chartered Surveyors (RICS). With the help of these groups of members in the industry, legislative issues which are deemed to be complex had been resolved and making UK-REITs not only the dream of the UK government through its introduction of nine REITs For the UK-REITs market to develop successfully in the near future, these three professional bodies are also committed to work together with the UK Government by playing the role in monitoring the development of the REITs.

Table 2: Process of UK-REIT regime being introduced

\begin{tabular}{|l|l|}
\hline Budget 2003 & $\begin{array}{l}\text { Announcements by the UK government to improve } \\
\text { flexibility and efficiency of the commercial property } \\
\text { market. }\end{array}$ \\
\hline Budget 2004 & $\begin{array}{l}\text { Consultation document was launched by the UK } \\
\text { government to sought views on how a property } \\
\text { investment fund (UK-REIT) might be structure }\end{array}$ \\
\hline March 2005 & $\begin{array}{l}\text { the Government published ' UK Real Estate } \\
\text { Investment Trusts: } \text { a discussion paper', along with a } \\
\text { summary of responses to the Budget 2004 } \\
\text { consultation }\end{array}$ \\
\hline Budget 2006 & $\begin{array}{l}\text { Chancellor Gordon Brown announced the full } \\
\text { details of the UK REITs regime }\end{array}$ \\
\hline $1^{\text {st } \text { January 2007 }}$ & \begin{tabular}{l} 
Introduction and enforcement of UK-REIT regime. \\
\hline
\end{tabular} \\
\hline
\end{tabular}

Source: REITA (2009) 


\subsubsection{The Mechanism of UK-REITs}

As similar as to other developed REITs industry countries, UK-REITs share the common characteristics, or more precisely the common advantage of its being tax free at the corporate level. Provided that if certain criteria had been fulfilled, the REITs Company will not be taxed for the rental income and gains arising from their investment property. Major part of the profit will directly flow through to the shareholders while they will then tax them for the dividend income received accordingly. Most of the REITs were converted from Property Companies during the effective day of REIT regime, which include British Land, Land Securities and Liberty International. However, when an existing company who wished to convert into UK-REIT, they are required to pay $2 \%$ of the fair market value of the property rental asset as the entry charge on the date of entry of REITs. The company is given the option to pay the entry charge in four instalments, where the first due must be on the date of the entry. The remaining three instalments may make on the first three anniversaries of that date of entry with the total aggregate charge equates to $2.19 \%$. This charge for the conversion to REITs status is deemed by the UK Government as the compensation for the future exemption of tax.

Furthermore, provided that not every company is able to convert into REITs status, the company needs to be a UK resident company and a close-ended investment company,( not a close company), have shares listed on a recognised stock exchange, loans on commercial terms only and issue one class of ordinary shares only. The REITs company is obliged to fulfill all these fundamental requirements in order to avoid the exclusion from REITs status. Any breach of conditions needs to be informed to HM Revenue \& Custums (HMRC) for action or penalty to be taken in the form of a charge in tax on the company. REITs company is also obliged to fulfil the interest cover test which must be not less than 1.25 for each accounting period. In other words, if the profit to debt ratio of a company is below 1.25, the company will be penalized in the form of a charge on tax according to the debt exceeded. This also equates to a gearing ratio of $80 \%$. Other than the interest cover test, there are also further conditions to be fulfilled by the company in order to continue operating as REITs. This is inclusive of the minimum of three properties involved in the property rental business, no single property over $40 \%$ of the total assets, to distribute at least $90 \%$ of the tax-exempted profits to the shareholders, at least $75 \%$ of the REIT's company total profit must be derived from the property rental business and at least $75 \%$ of the REITs company's assets must be involved in the property rental business.

\subsubsection{Market performance of UK-REITs}

The property sector in UK has been pushed up after the introduction of UK-REITs early in the year of 2007. As pointed out by Ernst \& Young in their global REITs report for year 2008, the size of the UK REIT market is impressive in terms of the market capitalization. The UK-REIT market capitalization had achieved up to US\$ 58 billion after six months of the introduction of REIT regime by the UK Government. It is further claimed in the report that UK was ranked as the fourth largest REITs country according to the total market capitalization. Significant growth seem to be continued and it is believed that the REITs market still needs some time to be stabilized and become more mature in the global REITs market.

As regard to the Global REIT Survey, in December 2008 by the European Public Real estate Association, they had mentioned that due partly to restrictive legislation and partly to lower rental yields; office, retail and industrial property had dominated the UK-REIT market, with no residential property REITs in the 
sector. Thus, this will require investors to actively churn residential property portfolios to make suitable returns. Encouraging this type of investor into the REIT market will depend on future legislative changes. However, REITs which own better quality assets and have lower gearing should be better equipped to survive such a difficult environment. The legislative changes are also expected in order for the growth in the REIT market in UK as outlined in the Ernst \& Young global REITs report 2008, where tax authorities allow the market to settle, thus legislative changes in UK REITs are expected to be minimal or at least over the short-term. However, further changes in the medium-term to further encourage growth in the REIT market in the UK are anticipated.

Upward movement as the first full year as tax-free REIT income flows through was expected because of the UK market is very aware that its dividend yields are lower than other REIT countries.

\subsection{M-REITs Vs UK-REITs}

\subsubsection{Legal Framework of REITs: Rules and Regulation}

A comparison of the REIT regime between Malaysia and United Kingdom will be explained in this section, which will be broken down into three segments, namely the organizational rules; income and asset rules; distributing rules, gearing restrictions and other considerations. The rules monitoring the mechanism of REITs industry are different in many ways and affects the development of REITs in their respective countries.

\subsubsection{Organisational Rules}

The organisation framework of a REIT company is essential to follow the set of rules determined by the country. However, the rules are generally similar between countries as shown in Table 3. The major distinctive between M-REITs and UK-REITs is M-REITs could either be listed or unlisted. Yet, UK-REITs must be a listed and close-ended company. No foreign company is allowed to be entered as UK-REITs as well. A management company will be appointed to manage any of the M-REITs after obtain the approval of SC. UKREITs are free to choose to appoint a company to manage the REITs or manage internally. Guidelines on the minimum fund size are different for respective countries. Foreign shareholders are also limited as for M-REITs.

Table 3: Organisational rules of REITs between Malaysia and United Kingdom

\begin{tabular}{|l|l|}
\hline \multicolumn{1}{|c|}{ Malaysia } & \multicolumn{1}{c|}{ United Kingdom } \\
\hline $\begin{array}{l}\square \text { Must be a registered trust approved by Securities } \\
\text { Commission (SC). } \\
\square \text { Can either be listed or unlisted }\end{array}$ & $\begin{array}{l}\square \text { Must be a close-ended1 company and listed on } \\
\text { London Stock Exchange or any other recognized stock } \\
\text { exchange. } \\
\square \text { The "principal company" (of a group of REIT) must } \\
\text { be a UK resident company. }\end{array}$ \\
\hline $\begin{array}{l}\square \text { Managed and administrated by a management } \\
\text { company approved by SC. }\end{array}$ & $\square$ Management of REIT may be internal or external. \\
\hline $\begin{array}{l}\square \text { Minimum fund size under the REIT Guidelines is } \\
\text { RM 100 million. Subsequent issuance of new units } \\
\text { shall be of minimum of RM 25 million by unitholders, } \\
\text { trustee and SC approvals. }\end{array}$ & $\begin{array}{l}\square \text { Must have a minimum share capital of GBP 50,000. } \\
\square \text { Must have only one class of ordinary share. The } \\
\text { participating fixed rate preference shares. }\end{array}$ \\
\hline$\square$ A maximum of 40\% foreign effective equity. & $\square$ No restriction on foreign shareholders. \\
\hline
\end{tabular}


\begin{tabular}{|l|l|}
$\square$ A qualified property manager to managed all the & $\square$ No additional landlord requirements.
\end{tabular} real property owned by REIT.

Source: EPRA Global REIT Survey December 2008

\subsubsection{Income and Asset Rules}

The investment activities of REITs are controlled by the regulation for both countries. The tax exempt status will only be granted when the specified portion of income is derived from qualifying investments. In this context, Malaysia and United Kingdom are having different rules. In the case of Malaysia, listed and unlisted REITs are having a slightly different set of rules as described in Table 4.

Table.4: Income \& assets rules of REITs between Malaysia and United Kingdom

\begin{tabular}{|c|c|}
\hline Malaysia & United Kingdom \\
\hline $\begin{array}{l}\text { Income of REIT must be derived from qualifying } \\
\text { investments. }\end{array}$ & $\begin{array}{l}75 \% \text { of the income of REIT must be derived from } \\
\text { qualifying investments to maintain its tax exempt } \\
\text { status. }\end{array}$ \\
\hline $\begin{array}{l}\text { For unlisted REITs: } \\
\square \text { At least } 70 \% \text { of the total assets must be invested in } \\
\text { real estate, single purpose companies or real estate } \\
\text { related assets. } \\
\square \text { At least } 50 \% \text { of the total assets must be invested in } \\
\text { real estate or single purpose companies. } \\
\square \text { At least } 20 \% \text { of the total assets must be invested in } \\
\text { liquid assets all the times. } \\
\square \text { The balance of } 10 \% \text { may invest in either real estate- } \\
\text { related assets, non-real estate-related assets or asset- } \\
\text { backed securities. }\end{array}$ & $\begin{array}{l}\text { Property development and other trading are } \\
\text { permitted but will be taxed under the normal } \\
\text { corporation tax rate. }\end{array}$ \\
\hline \multirow[t]{4}{*}{$\begin{array}{l}\text { For listed REITs: } \\
\square \text { At least } 75 \% \text { of the total assets must be invested in } \\
\text { real estate, single purpose companies or real estate } \\
\text { related assets. } \\
\square \text { At least } 50 \% \text { of the total assets must be invested in } \\
\text { real estate or single purpose companies. } \\
\square \text { Liquid assets are not required to be invested all the } \\
\text { times } \\
\square \text { The balance of } 25 \% \text { may invested in either real } \\
\text { estate-related assets, non-real estate-related assets or } \\
\text { asset-backed securities }\end{array}$} & $\begin{array}{l}\text { At least } 75 \% \text { of the total gross value assets must } \\
\text { made up of qualifying investment properties, which } \\
\text { may be commercial or residential in or outside UK. }\end{array}$ \\
\hline & $\begin{array}{l}\text { Hold at least three properties, with no asset } \\
\text { representing exceed } 40 \% \text { of the market value of total } \\
\text { portfolio. }\end{array}$ \\
\hline & $\begin{array}{l}\text { Rental income generated from owner occupied } \\
\text { properties will not qualify as tax exempt profits. }\end{array}$ \\
\hline & $\begin{array}{l}\text { Sale of developed properties } 2 \text { may subject to tax if } \\
\text { there are disposed within three years of any. }\end{array}$ \\
\hline
\end{tabular}

Source: EPRA Global REIT Survey December 2008 


\subsubsection{Distribution Rules}

Distribution of income to its unit-holders is compulsory. At least $90 \%$ of the total income is required to be distributed in the form of dividends to its unit-holders. Table 5 shows the requirements.

Table 5: Distribution rules of REITs between Malaysia and United Kingdom

\begin{tabular}{|l|l|}
\hline \multicolumn{1}{|c|}{ Malaysia } & \multicolumn{1}{c|}{ United Kingdom } \\
\hline $\begin{array}{l}\text { Tax is exempted for the income of REIT, provided } \\
\text { that the condition of distributing 90\% of the total } \\
\text { income for the year to the unit holders had met. } \\
\text { Otherwise, the REIT will tax on its total income. }\end{array}$ & \begin{tabular}{l} 
Property income distribution (PID) must be at least \\
$\begin{array}{l}\text { Po\% of income generated from qualifying activities } \\
\text { must be distributed by the filling date of the } \\
\text { company tax return. }\end{array}$ \\
\hline
\end{tabular} \\
$\begin{array}{l}\text { PID are subjected to 22\% withholding tax (the basic } \\
\text { rate for UK income tax), unless they are distributed } \\
\text { to UK corporate, authorized investment funds and } \\
\text { certain pension fund. }\end{array}$ \\
\hline
\end{tabular}

Source: EPRA Global REIT Survey December 2008

\subsection{Findings and Discussions}

\subsection{The Performance Analysis}

The performance of REITs will be analysed for five aspects in this study. This would be inclusive of the total revenue, net income, total return, dividend yield as well as price earnings ratio. These five elements are considered the main financial components to measure performance and would be sufficient to demonstrate the company profitability, the return offered to their investors as well as the value of the company share. Total Revenue (including Revenue, Net Sales, or Sales) is the gross revenue minus the costs associated with returned or undelivered goods and commissions. Total Revenue on the other hand is simply all positive revenues. This distinction is particularly important for certain sectors like REIT which relies heavily on commissions and dividends which can experience frequent returned items. Thus, total revenue is the key component to measure performance for REIT organisation.

The main source of income for REITs was through the rental properties by way of collecting regular monthly rental. Other sources of income apart from rental income may include the service charge in relation to the rental properties, car park income and interest income. Thus, it could be concluded that the revenue was generally stable in nature due to the regular rental income from tenants of the rental properties owned by REITs company. A growth in total revenue is always expected by both the company as well as the unit holders of the REITs. This is owing to the reason that the dividend received by the unit holders will be affected by the total revenue generated by the REITs company for the respective financial year. 


\subsection{Total Revenue}

\subsubsection{M-REITs}

Starhill REIT's total revenue seemed to be stable for the two years at an average of RM 103.535 million per annum. Axis REIT's total revenue was almost half of Starhill REITs at an average of RM55.075 million per annum. This was not an unordinary situation whereby the property portfolio of Starhill REITs was inclusive of high end shopping center, namely Starhill Galery, with the ability to generate high and greater rental income. Axis REIT which focuses on office and warehouse sectors received a lower rental income.

Meanwhile, UOA REITs recorded the lowest total revenue among the three REITs at an average of RM 38.11 million per annum. The company concentrated on managing and letting office properties which generates lower rate of rental as compared to retail spaces. Nonetheless, the three M-REITs achieved a growth in terms of total revenue for the two consecutive years. It indicates a good sign for the REITs company because it reflects that the rental properties had a good and stable vacancy rate which contributed to the steady cash flow.

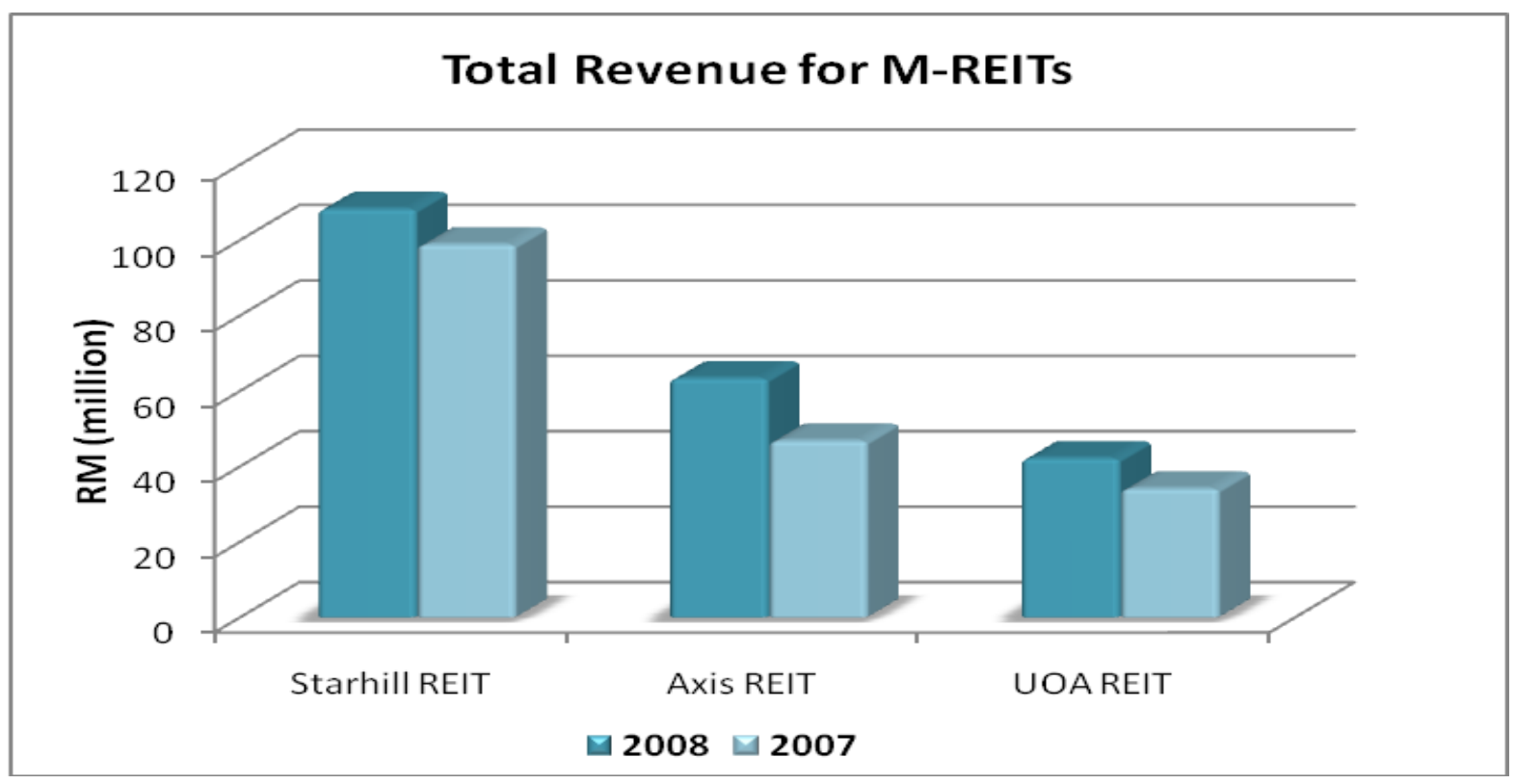

Figure 2: Total Revenue for M-REITs

\begin{tabular}{|l|c|c}
\hline \multirow{2}{*}{} & \multicolumn{2}{|c}{ Total Revenue (RM million) } \\
\cline { 2 - 3 } & $\mathbf{2 0 0 8}$ & $\mathbf{2 0 0 7}$ \\
\hline Starhill REIT & 108.23 & 98.84 \\
\hline AXIS REIT & 63.33 & 46.82 \\
\hline UOA REIT & 42.12 & 34.10
\end{tabular}

Table 6: Total Revenue for M-REITs, 2007-2008 


\subsubsection{UK-REITs}

As observed from the chart above, Land Securities had experienced a significant drop of total revenue in year 2008 as compared to the previous year. This was due mainly to the loss of income from insolvencies and increased voids. The UK economy which moved into recession had impacted the performance of UK-REITs. There is weaker demand from occupiers and pressure on the rental values. Yet it is still recognized as having the highest revenue among the three largest UK-REITs.

British Land with their property portfolio being focused at the retail and office sector has no way escaped from the impact of the economic downturn. The commercial property market of UK has suffered a significant impact which lead to the drop of income from the investment of rental properties. It was only Liberty International which was achieving growth of total revenue even in the tough economy conditions, having recorded a rise of $10.8 \%$ from $£ 548.7$ million to $£ 607.9$ million.

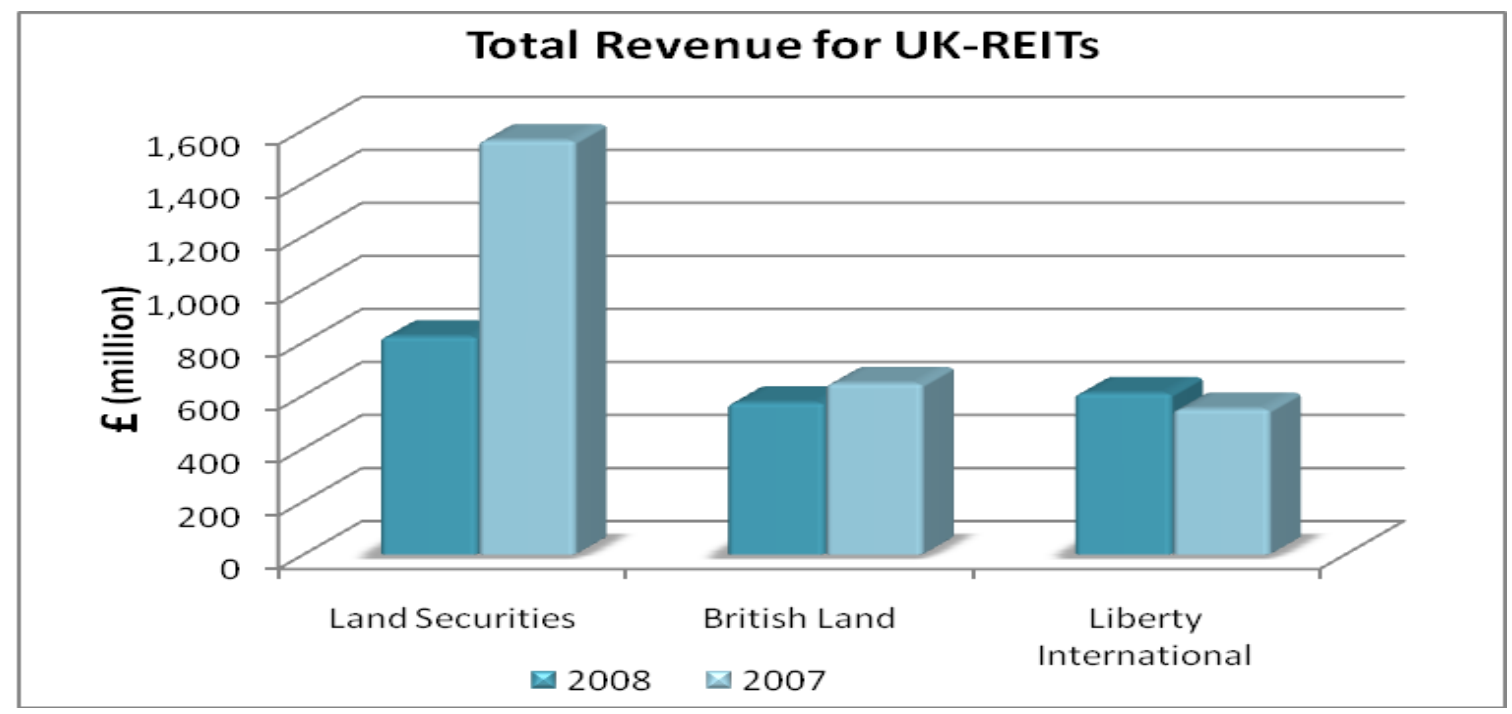

Figure 3: Total Revenue for UK-REITs

\begin{tabular}{|l|c|c}
\hline \multirow{2}{*}{} & \multicolumn{2}{|c}{ Total Revenue (£ million) } \\
\cline { 2 - 3 } & $\mathbf{2 0 0 8}$ & $\mathbf{2 0 0 7}$ \\
\hline Land Securities & 821.20 & 1561.20 \\
\hline British Land & 572.00 & 645.00 \\
\hline Liberty International & 607.90 & 548.70 \\
\hline
\end{tabular}

Table 7: Total Revenue for UK-REITs, 2007-2008

The revenue generated by M-REITs and UK-REITs show a tremendous difference. It can be observed that the UK-REITs received approximately ten times greater revenue than M-REITs. The situation can be explained by taking into account the number of investment properties owned by the REITs of the respective countries. M-REITs have a small size of investment property portfolio while the UK has the opposite situation. Thus, this has lead to the different scenarios where the total revenue is much greater for UK-REITs. 


\subsection{Net Income}

Net income is derived after deductions of the property operating expenses and other relevant costs incurred in managing the REITs. In performance analysis, net income is important as it plays a crucial role in determining the dividend to be paid out for unit holders for the specific financial year. The greater the net income, the unit holders would expect greater or more substantial returns.

\subsubsection{M-REITs}

From the chart above, it is realized that Starhill REIT being the largest M-REITs in terms of market capitalization had recorded the highest net income for the two year study period. A growth of $11.8 \%$ is achieved by Starhill REIT in the year 2008. This increment of net income was owing to the higher rental rates from existing tenancies as well as the commencement of new tenancies.

Yet, Axis REIT has recorded a higher growth rate in terms of net income which is about $39 \%$ despite a reduced average vacancy rate for the portfolio respectively in the year 2008. Simultaneously, UOA REIT has recorded a rise due to the strong occupancy of all rental properties. Net revenue had recorded at an average of RM 23.21 million per annum.

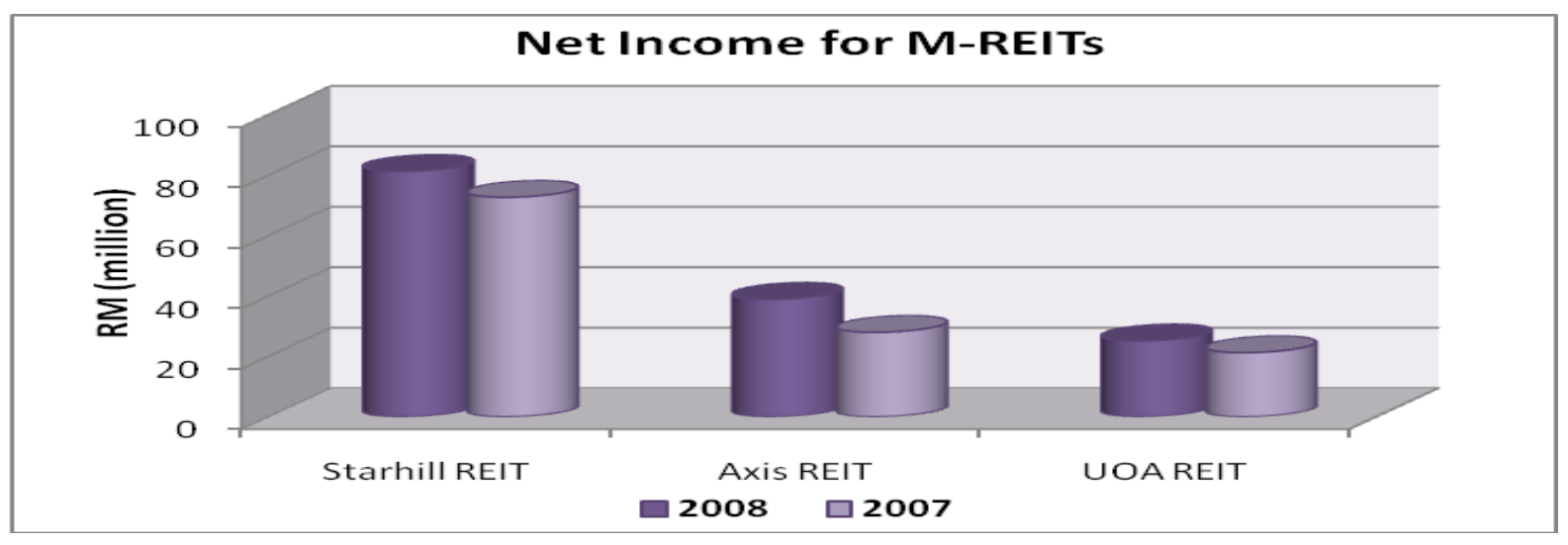

Figure 4: Net Income for M-REITs

\begin{tabular}{|c|c|c|}
\hline & Net Imcome & million I \\
\hline & 2008 & 2005 \\
\hline Starlfoill ReEIT & B1.27 & 72.69 \\
\hline Aucis REIT & 38.97 & 27.99 \\
\hline WOA REET & 25.18 & 21.24 \\
\hline
\end{tabular}

Table 8: Net Income for M-REITs, 2007-2008

\subsubsection{UK-REITs}

As shown above, the net income made by UK-REITs was in deficit for the two consecutive years. According to the Wall Street Journal, UK commercial property market was in a very tough condition since the introduction of UK-REITs regime and the conversion of the three UK-REITs as shown above at $1^{\text {st }}$ January 2007. Property values were experiencing a sharp fall as was pointed out by the finance director of Land Securities in the annual report of Land Securities as at the financial year ended $31^{\text {st }}$ March 2009. A release by 
the Nareit Global Real Estate Index (a global benchmark of REIT performance) in April 2009 showed that the overall UK commercial property returns had fallen for about $8.3 \%$.

The scenarios above has significantly impacted the financial results of each of the UK-REITs company. As a result, a loss after tax of $£ 4.857$ million, $£ 3.881$ million and $£ 2.451$ million was borne by the Land Securities, British Land and Liberty International respectively. This was also due mainly to a revaluation of the deficit for most of their properties in the portfolio. It was also noted that the performance was even worse for year 2008 as compared with 2007. Greater deficit in net income was shown in year 2008 and Land Securities with the most amount of property in their portfolio had suffered the most loss.

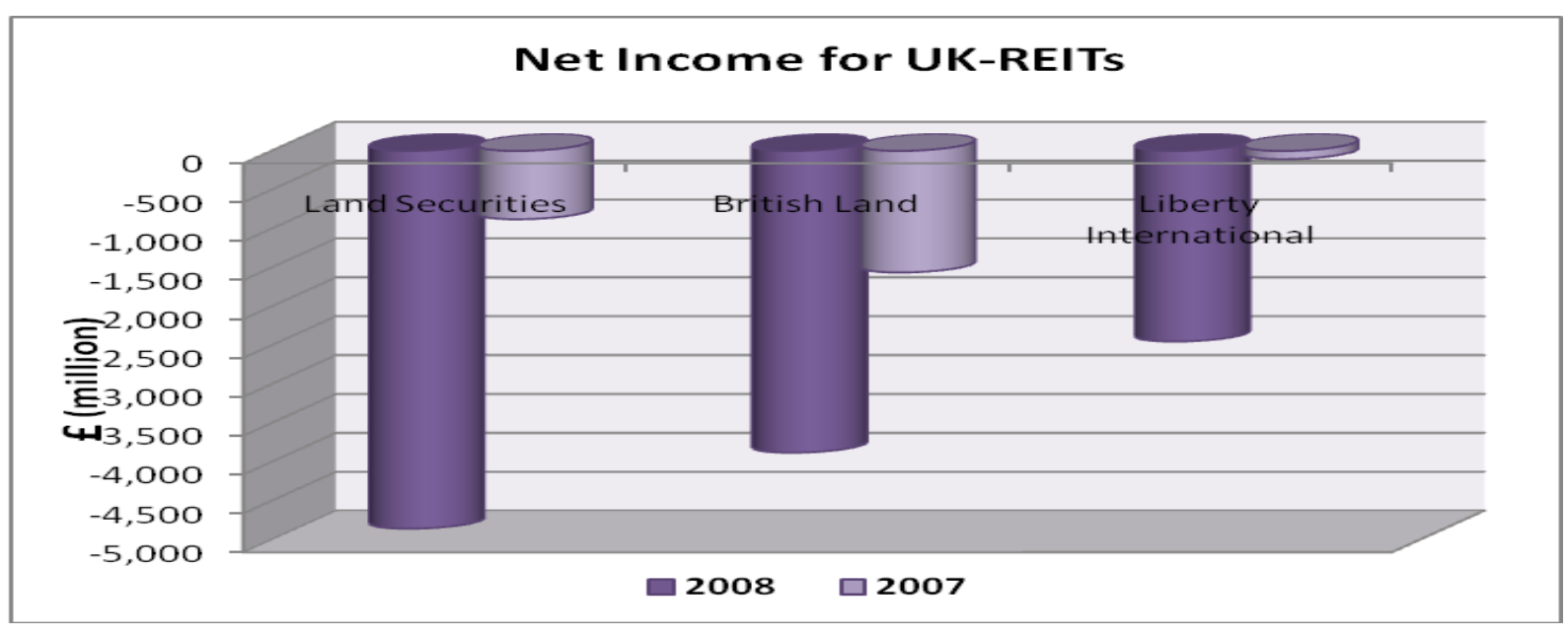

Figure 5: Net Income for UK-REITs

\begin{tabular}{|l|c|c}
\hline \multirow{2}{*}{} & \multicolumn{2}{|c}{ Net Income (E million) } \\
\cline { 2 - 3 } & $\mathbf{2 0 0 8}$ & $\mathbf{2 0 0 7}$ \\
\hline Land Securities & $-4,857.70$ & -878.30 \\
\hline Liberty International & $-3,881.00$ & $-1,563.00$ \\
\hline
\end{tabular}

Table 9: Net Income for UK-REITs, 2007-2008

As a whole, the scenario of UK-REITs was worse than M-REITs in terms of net income at the moment. It is hoped that it is just an interim for the REITs sector in the UK. Fortunately most of the REITs company are property companies with strong base before the conversion into REITs status. Thus, even in such challenging conditions, they will be able to sustain their positions.

M-REITs is considered much more stable than UK-REITs as the property market is dissimilar with the UK property market. Furthermore, even though there might be a loss in the revaluation of property, due to the smaller amount in properties owned, it would not lead to a deficit in net income.

\subsection{Total Return}

Total return is the return that an investor could realized from a particular investment. It is a tool to evaluate the performance of an investment. A positive total return indicates a profit driven investment. The 
investor will then tend to determine the extent of the total return and compare this among other investment choices. Whereas a negative total return will result in the unwillingness of the investors to invest. Although all the REITs company aimed to enhance return to their unit-holders, sometimes, the company has limited control on the traded price of their company, for instance, the market risks have effects and sometimes the residual effect of a financial crisis might be seen.

\subsubsection{M-REITs}

In the year 2007, all the three M-REITs have had a positive total return ranging from $17 \%$ to $32 \%$. UOA REIT has recorded the highest total return though it is the smallest REIT in terms of market capitalization among the three M-REITs.

It was considered be the best performing REIT in 2007 when it offered $32.67 \%$ to the investors. Consistent and conceptualized, innovative marketing and operating strategies adopted by Starhill REIT was to ensure lucrative returns to their unit holders. In the year 2007, 24.26\% return was given by Starhill REIT, slightly lower as compared to UOA REIT. Axis REIT was also considered offering an excellent return, namely $17.29 \%$, which was low risk in nature as compared to the investments in the vigorous movement of share markets where the need to bear a higher risk prevails.

In, the year 2008, all the three M-REITs recorded a negative total return, with the maximum of $31.31 \%$ for Axis REIT. It was observed that Axis REIT was traded at RM 1.85 at the early part of 2008 yet closed at RM 1.12 at the end of the year. It was due to the fallout of the financial crisis whereby the unit price of Axis REIT along with other M-REITs and equities generally were not spared as pointed out in the Axis REIT Annual Report 2008. This directly explained the same scenario faced by the other two M-REITs. Investors' confidences toward the REIT market as well as the stock market were affected significantly, which is believed to be one of the reasons for the scenario above.

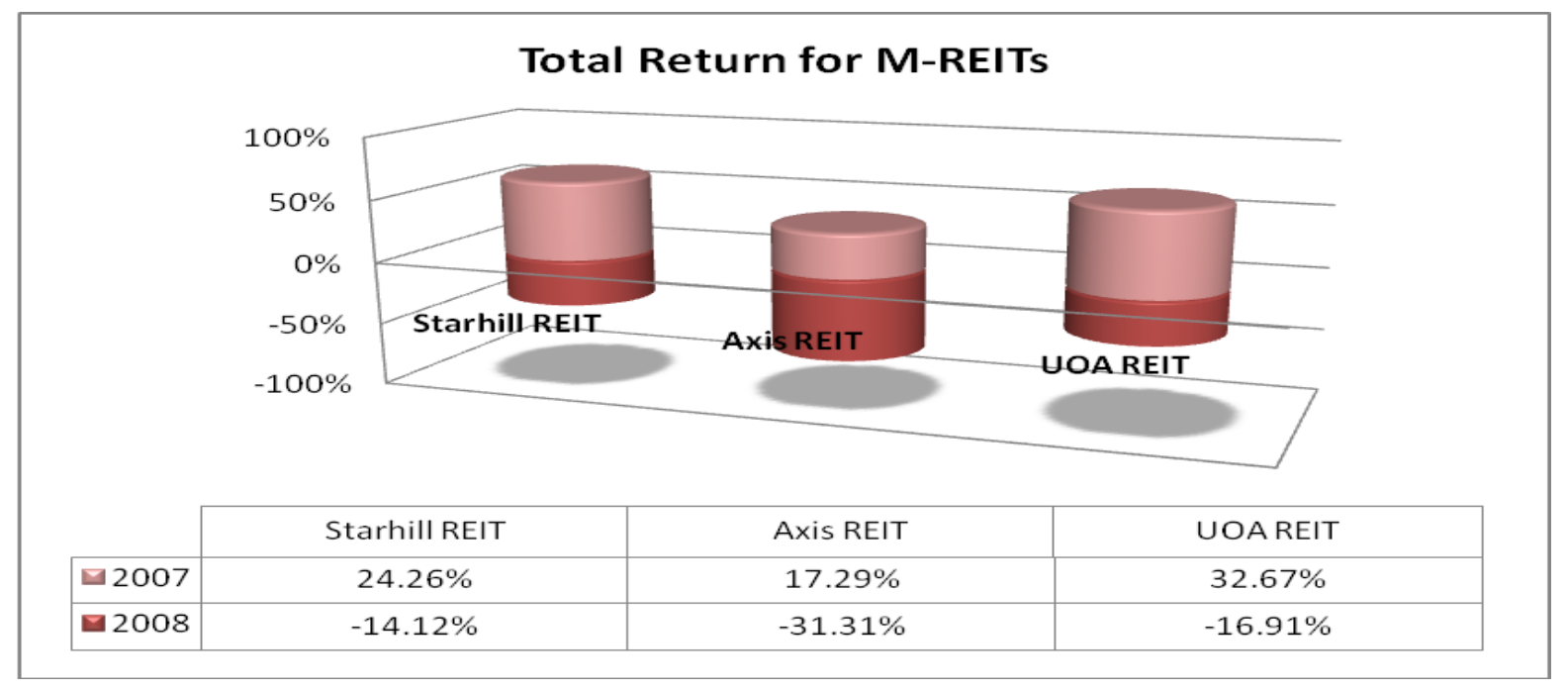

Figure 6: Total Return for M-REITs 


\subsubsection{UK-REITs}

In the UK context, it was again in deficit figures in the net income. The unstable property market of UK particularly the commercial property market has affected the confidence of investors toward REITs share. Total return of Land Securities was among the lowest performing UK-REITs, which was $-14.34 \%$ and $-9.6 \%$ greater than British Land and Liberty International respectively in year 2008.

From the observation of the market trade, the three largest UK-REITs were traded much more lower at the closing of year 2008 as compared with the traded price in the early part of the year. This would definitely lead to the greater deficit in year 2008. This should be a worry as the investors may choose to quit investments in the REIT and invest in other sectors

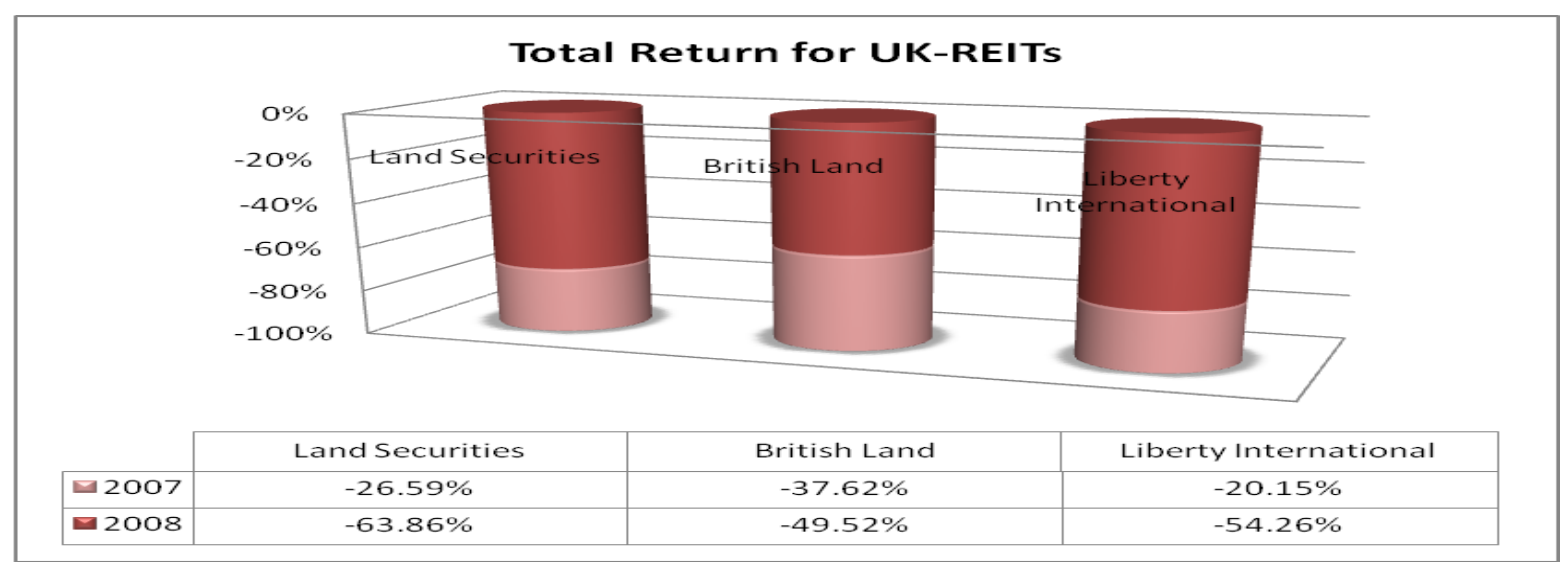

Figure 7: Total Return for UK-REITs

Total return of REITs for both countries was performing poorly in the year 2008 as compared with 2007. The UK-REITs was in a poorer situation since both the years were giving a deficit total return. In the opinion of most investors, it would probably not be a choice of investment for them.

\subsection{Dividend Yield}

Dividend yield indicates the ratio of return by the company that goes to the shareholders in the form of dividend. (Dividend Yield = Annual Dividend per Share /Stock's Price per Share (Source:http://www.stockmarket-investors.com/pick-a-stock-guides/dividend-yield-explanation.html).

This ratio measures the percentage of a share's market value that is returned annually as dividends, being a vital concern of shareholders. Investors use the ratio in determining their return by putting their money at risk and for a period of time. It is usual that an investor will decide to invest in any REITs which offer high dividend payout while choosing among the investment tools.

\subsubsection{M-REITs}

Generally, the dividend yield of M-REITs was above the return of fixed deposit which is at an average of 2-3\%. Though the dividend yield may not as high as the return from investing in stock market, REITs involve lesser risk due to the regular rental income flow from their rental properties.

Axis REIT offering the highest dividend yield for the two consecutive years, namely $13.46 \%$ and $6.51 \%$ for 2008 and 2007 respectively. The distribution per unit (DPU) was announced by Axis REIT at 15.27 
sen per unit for year 2008, increase from the previous year at RM 13.63 sen, representing an increase of $12 \%$. Starhill REIT was slightly lower for the dividend yield, yet it was still increased from 2007 to 2008, namely from $6.26 \%$ to $8.11 \%$.

As complying with the objective of UOA REIT, i.e. to achieve stable and attractive returns for its unit holders, the dividend distributed by UOA REIT has recorded a growth in dividend yields as well, 7.17\% and 4.79\% for year 2008 and 2007 respectively. Though it is among the lowest of the three M-REITs, it should considered to be a moderate investor and an investment with the ability for receiving a stable and regular income with the low risk characteristic of REITs.

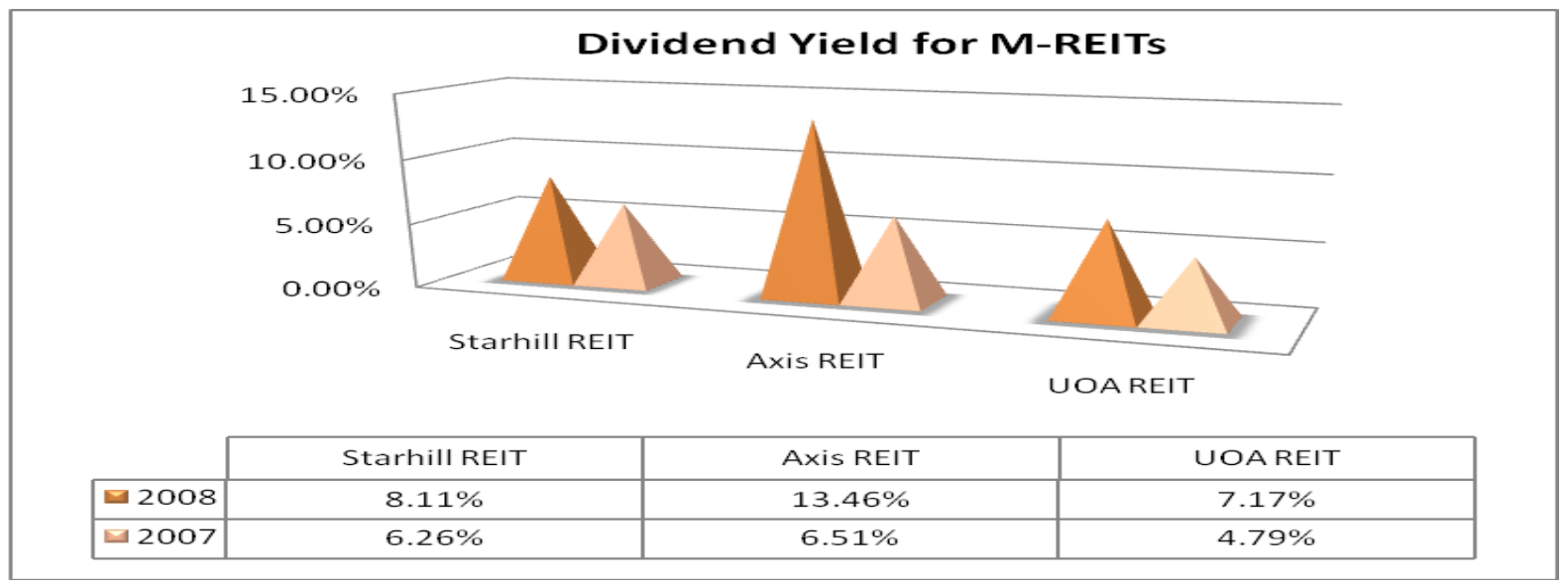

Figure 8: Dividend Yield for M-REITs

\subsubsection{UK-REITs}

The three largest UK-REITs was giving dividend yields ranging from $3 \%$ to about $11 \%$.In fact, it was increased by nearly half from year 2007 to 2008, except Liberty International which had only a $0.09 \%$ increase. Land Securities was careful in determining the dividend to be paid for unit holders to ensure that their dividend remain realistic and sustainable as well as the other two UK-REITs. Dividend payment is giving by taking the current economic and market environment into consideration to ensure future earnings. Generally Land Securities was the highest in dividend yield with nearly $11 \%$ in year 2008 and $4.25 \%$ in year 2007. As compared with British Land, it was about 6.45\% in year 2008 and 3.81\% in year 2007. Whereas Liberty International was being the UK-REITs having the lowest dividend yield at only 3.09\% and 3\% in year 2008 and 2007 respectively.

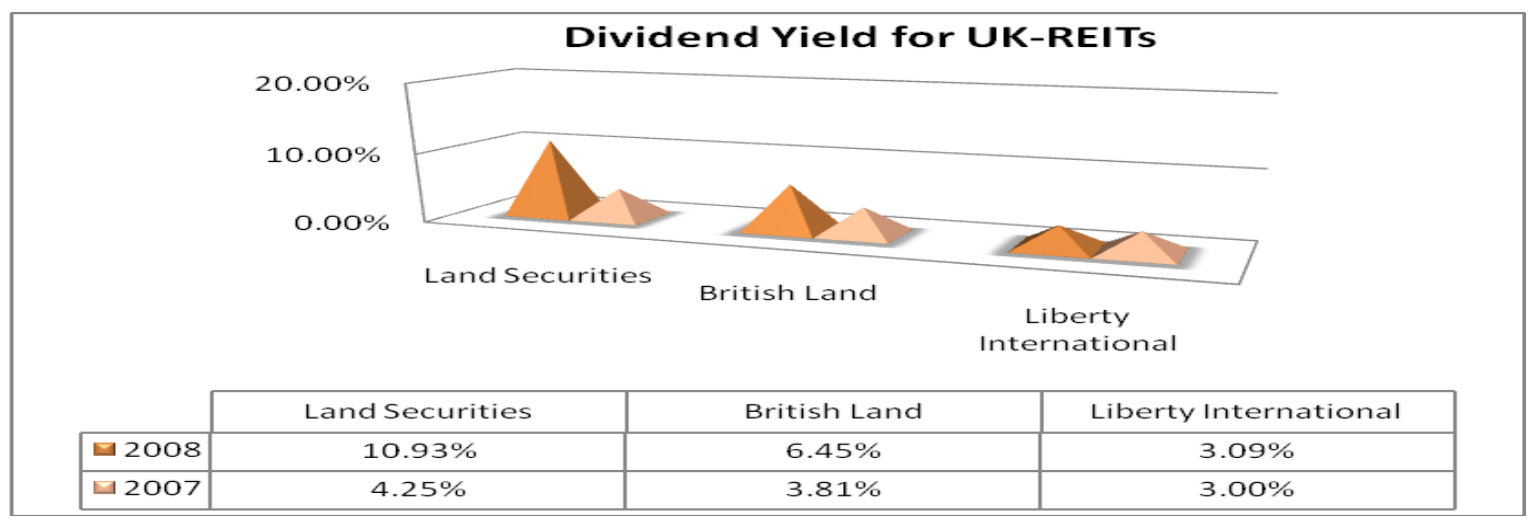

Figure 9: Dividend Yield for UK-REITs 
As a whole, M-REITs were having a higher dividend yield than UK-REITs. Though it was not a great difference. The amount distributed in the form of dividends largely depends upon the decision by the respective management of the REITs taking into consideration several factors. The different economic climate as well as the property market conditions would probably affect the decision of the REITs management in matters of dividend payout.

\subsection{Price to Earnings Ratio (PE Ratio)}

The price/earnings ratio is the ratio of the market price of an ordinary share to the company's earnings per share (EPS). This ratio, abbreviated as P/E, can be easily calculated using the information on EPS and share price.

It was one of the oldest ways to demonstrate the value of a company share, where it will also be deemed to be an indicator of a company's profitability. In addition, it gives an indication of the confidence that investors have in the future prosperity of the particular business. Companies having a P/E ratio of 1 indicates very little confidence by investors whereas $\mathrm{P} / \mathrm{E}$ ratio of 20 expresses a great deal of positivity towards the future of the particular company (http://www.bized.co.uk/compfact/ratios/investor12.htm).

\subsubsection{M-REITs}

The PE ratio as computed was highest for Starhill REIT at $12.34 \%$ and $15.57 \%$ for 2008 and 2007 respectively. Starhill REIT commanded a PE ratio of exceeding 12 indicating that it was considered to be large caps company on Bursa Malaysia. This could be verified such that the market capitalization in the year 2007 and 2008 was RM 222 and RM 333. Both the Axis REIT and UOA REIT was having a PE ratio below 12, indicating that they were a small company on Bursa Malaysia. It can be observed that the confidence of investors toward UOA REIT had increased as the PE Ratio had increased tremendously from 3.39\% to $10.45 \%$. Whereas Starhill REIT and Axis REIT both suffered a drop in PE ratio from 2007 to 2008, but, fortunately it was not significant.

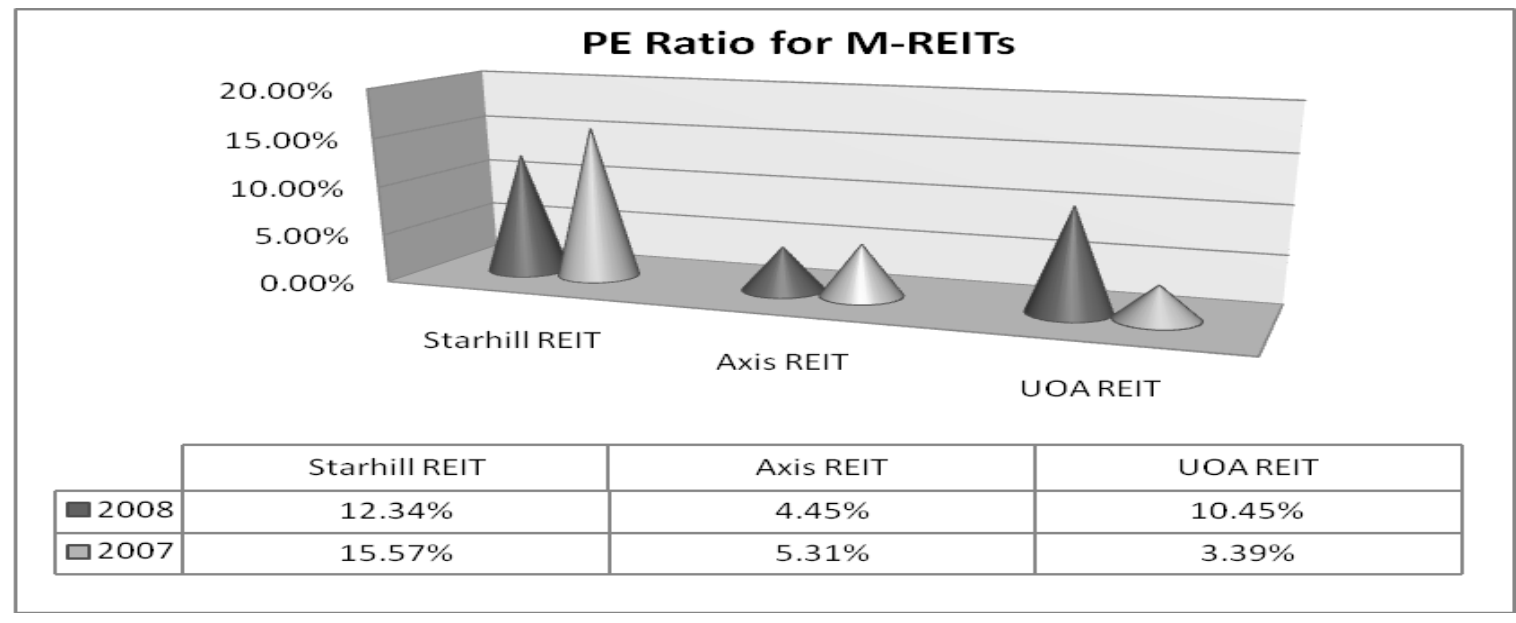

Figure 10: PE Ratio for M-REITs 


\subsubsection{UK-REITs}

Differs from the M-REITs, PE ratio for all the three largest UK-REITs was in a negative figure. From the formula of PE ratio, a negative figure would probably occur when either the numerator or denominator is found to be below zero. Since the numerator, the share price of REITs will not hit to a deficit value, thus a negative PE ratio indicated the company was losing money where the denominator, earnings per share is below zero. This could be verified such that the net income analysed in the earlier part showed that all the three UKREITs was in fact experienced a loss after tax.

In year 2007, PE ratio of Liberty International was the highest in terms of deficit, $-37.34 \%$. It had far more deteriorated as compared with the other two UK-REITs with only $-7.988 \%$ and $-3.01 \%$ for Land Securities and British Land respectively. However in the following year, all the three increased their PE ratio to nearly achieve zero or move towards a positive PE ratio.

The PE ratio appears to be in an opposite situation for M-REITs and UK-REITs. The loss experienced by UK-REITs was the main cause of the negative PE ratio. However it improved in year 2008 and it is believed that appropriate strategies should be taken by the respective REITs company to sustain and improve the PE ratio as it is an important indicator for the performance of a company to the investors as a whole.

M-REITs is in a better position but would still need to put in more effort in enhancing the company profit in building more investors' confidence toward the M-REITs company.

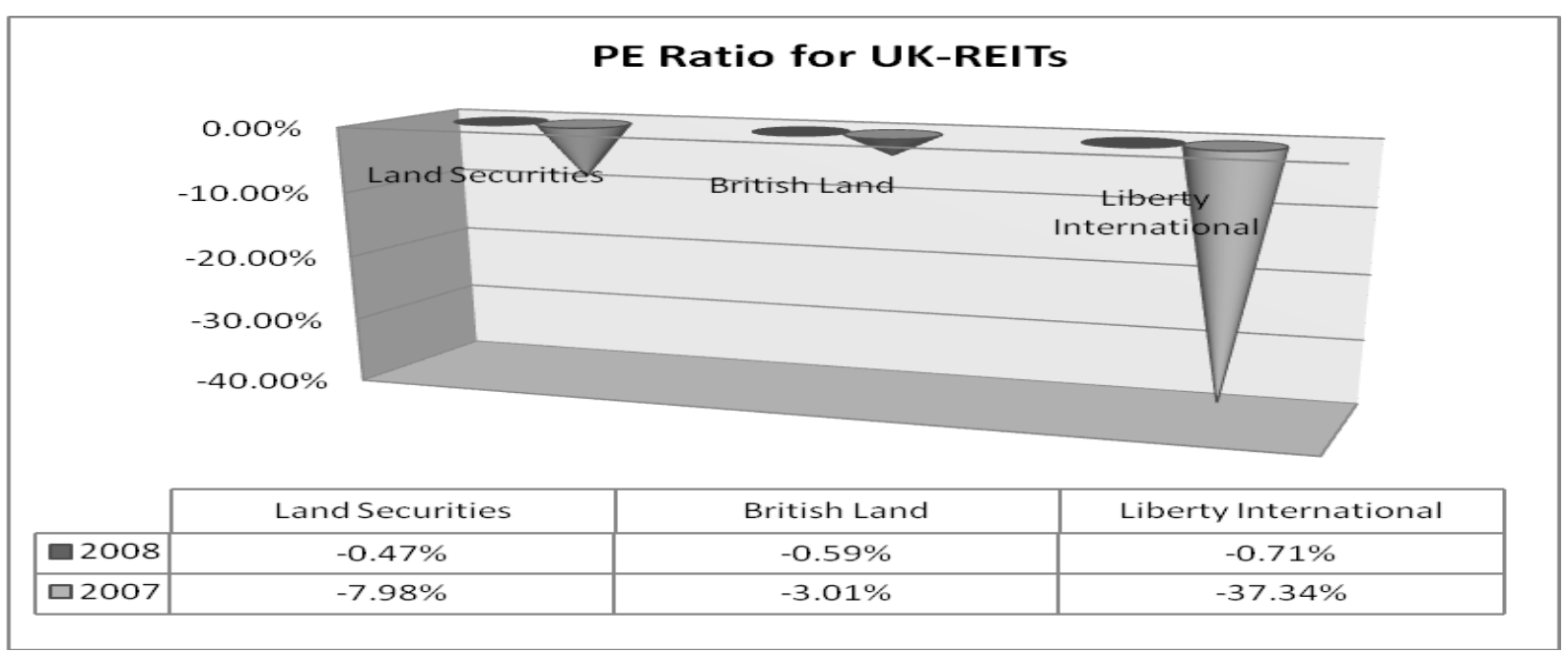

Figure 11: PE Ratio for UK-REITs

According to the analysis, it could be concluded that although the total revenue generated by UKREITs was much greater than M-REITs, yet, due to the steep falls in property asset value, the selected UKREITs have all suffered a loss after tax. Nevertheless the selected M-REITs were in a better position than UK where the total return and P/E ratio demonstrated a gratifying figure. UK-REITs were instead reflecting a deficit figure. Dividend yields in fact was greater for M-REITs rather than UK-REITs. 


\section{Conclusion}

The findings and analysis of the research showed that the total revenue was the main factor affecting the performance for both the largest M-REITs and UK-REITs. This finding is consistent with the study done by Ambrose and Linneman (2001) which concluded that the larger the size of REITs, the higher the rental revenue and profit margin. Furthermore, they also demonstrated that for every billion increase in market capitalisation, the profit margins generated by the REITs will raise by approximately $9 \%$. The largest REITs indicate that they have the largest in market capitalisation. As the largest REITs, share capital would basically be huge and with the huge amount of capital raised from the unit holders, the management would afford to investing in property which is more prominently placed and offering higher returns to the REITs. For instance, Starhill Gallery which is owned by Malaysia's largest REIT, Starhill REIT, is a renowned and high-end shopping complex situated in the Heart of Kuala Lumpur's Golden Triangle Area. Their tenants were made up of notable tenants from over 70 luxurious brands. Thus, the revenue received would undeniably be higher. In addition, the amount of investment properties held in the portfolio will also be in line with the size of the REITs.

By looking at the UK's largest REITs, Land Securities, they owned over 200 properties in prominent locations with the ability to generate higher rental. The total revenue was also the highest among all UK-REITs. Besides, the factor of the investment properties included in the REITs portfolio, there was also another determinant of revenue generated. In fact, commercial properties were offering higher rental rates than residential properties as well as industrial properties. Whereas in the categories of commercial properties, retail was indeed higher in rental value than office properties depended on location. From the analysis done, the statement above could be supported by comparing the portfolio of the three (3) largest M-REITs. Revenue generated by Starhill REITs was higher than Axis REIT and UOA REIT. In fact, Starhill REIT has a retail focus REIT with two prominent and strategic located shopping complexes while Axis REIT and UOA REIT focused on offices cum warehouse industrial properties and offices respectively. Furthermore, as pointed out by Capozza and Seguin (2002) in their study of externally advised REITs incurred more debt as compared with internally advised REITs. It is owing to the reason that externally managed REITs incur management fees which increases the administrative expenses. This was rejected in this study where the M-REITs which are externally managed had in fact a better performance in terms of net income (after deducting all the operating expenses and other relevant costs incurred) as compared with UK-REITs which are internally managed.

In conclusion, the performance of a REIT is driven by numerous factors. The factors pointed out in this research are not necessarily applicable for all REITs in the world. The REITs regime adopted for a different country is varied but to a certain extent it can be applied. The findings are also useful for policy makers, REITs investors and companies to set a policy for REITs in both countries. However, a detailed study has to be carried out before generalising on the factors affecting performance of REITs. 


\section{References}

Ambrose, B. \& Linneman, P. (2001) REIT organizational structure and operating characteristics.

Journal of Real Estate Research. 21(3), 141-162.

Angie Ng. (2009, July 6). More REITs seen with easing of guidelines. The Star, p.Business. Retrieved October

21,2009 , from

http://biz.thestar.com.my/news/story.asp?file=/2009/7/6/business $/ 4255234 \&$ sec=business

Angie Ng. (2009, August 17). Room for more listed REITs in Malaysia.

Retrieved October 21, 2009, from

http://biz.thestar.com.my/news/story.asp?file=/2009/8/17/business/4525773\&sec=business

Anonymous. (2009). Definition of volatility. Retrieved October 23, 2009, from

http://financial-dictionary.thefreedictionary.com/volatility

Bized Uk. (2010). Definition of Price to Earnings Ratio. Retrieved March 31, 2010, from http://www.bized.co.uk/compfact/ratios/investor12.htm

Block R. L. (2006). Investing in REITs : Real Estate Investment Trust. 3rd Ed.,New York: Bloomberg Press.

Capozza, D. R. \& Seguin, P. J. (2002). Debt, Agency and Management Contracts in REITs: The External Advisor Puzzle. Journal of Real Estate Finance and Economics. 20(2), 91-116.

Chin,Y. H.\& Rubi Ahmad. (2006). An Evaluation of the Performance of Malaysian Real Estate Investment Trusts (M-REITs) 1990-2006. Proceeding of Asia Pasific Management Conference XII.

Ernst \& Young. (2008). Riding out the storm. Global Real Estate Investment

Trust Report 2008. Retrieved October 17, 2009, from

http://www.reita.org/pages/resources/downloads/Property_investment_global/

EY_Global_REIT_report_2008.pdf

European Public Real Estate Association \& Ernst \& Young. (2008). A comparison of the major REIT regimes around the world. Global REIT survey December 2008. Retrieved October 17, 2009, from http://www.reita.org/pages/resources/downloads/Property_investment_global/EPRA_REIT_Survey_20 08.pdf

European Public Real Estate Association (2004) EPRA Global REIT Survey, September, EPRA. The Netherlands, pp 28.

Imperiale, R. (2006). Getting Started in Real Estate Investment Trust. New Jersey: John Wiley \& Sons Inc.

IPF (Investment Property Forum). (2007). A Guide for Financial Advisers.

Retrieved October 17, 2009, from

http://www.reita.org/live/resources/downloads/REITs_Guides/ifa_guide_May07.pdf

Islamic REITs and capital development. Retrieved October 21, 2009, from http://www.iifm.net/LinkClick.aspx?fileticket=YqD8\%2B117ZNg\%3D\&tabid=86

Joseph T. L., Ooi, Newell G., T.F. Sing. (2006). The Growth of REITs market in Asia. Retrieved September 24, 2009, from http://business.fullerton.edu/finance/jrel/papers/pdf/past/2006vol14n2/03.203_222.pdf 
Newell, G., Ting, K.H. \& Acheampong, P. (2002) Listed Property Trusts in Malaysia. Journal of Real Estate Literature. 10(1).109-18.

Petersen, A. (2004). The major issues facing the successful introduction of the UK REIT. Briefing in Real Estate Finance. 4(1), 8-20. Retrieved September 24, 2009, from http://www.abanet.org/rppt/meetings_cle/joint2004/JointSectionPrograms/TendsinForeignRealEstateIn vestment/Andrew\%20Petersen--Major\%20Issues\%20and\%20UK\%20REIT.pdf

Phuah, Cheryl S.L. (2005). Real Estate Investment Trusts. Kuala Lumpur: Quarterly Buletin of Securities Industry Development Centre, Securities Commission Malaysia.

Reita. (2009). All about REITs. Retrieved October 17, 2009, from http://www.reita.org/live/For_advisers/Property_investment_overview/about.html

Reita. (2009). Commercial property development. Retrieved October 17, 2009, from http://www.reita.org/live/For_advisers/Property_investment_overview/commercial.html

Securities Commission. (2009). List of M-REIT. Retrieved October 21, 2009, from http://www.sc.com.my/eng/html/resources/stats/REIT.pdf

Shahrin Shaikh Mohd. (2006). REITs in Malaysia: a regulator's perspective. Seminar on Real Estate Investment Trust - Challenges In the 21st Century (28 February 2006: Kuala Lumpur)

Stock Market Investors. (2010). Dividemd Yield Explanation. Retrieved March 29, 2010, from http://www.stock-market-investors.com/pick-a-stockguides/dividend-yield-explanation.html

Thomsom ONE Banker. (2010). Financial data od REITs companies. Retrieved 21 March, 2010 from http://banker.thomsonib.com/.

Ting, K.H. (1999). The Listed Property Trusts Industry in Malaysia: Factors Constraining its Growth and Development. Proceedings of International Real Estate Society Conference '99. Kuala Lumpur.

5. Ting, K.H. (2002) Real estate investment trusts: will they take-off? Australian Property Journal. 50-54. 